\title{
Learning Geometry through Discovery Learning Using a Scientific Approach
}

\author{
Akhsanul In'am \\ Mathematics Department University of Muhammadiyah Malang Indonesia, Indonesia, \\ ahsanul_in@yahoo.com

\section{Siti Hajar} \\ Islamic Junior High School Malang Indonesia, Indonesia, sitihajar5665@yahoo.co.id
}

\begin{abstract}
The objective of this present research is to analyze the implementation of learning geometry through a scientific learning consisting of three aspects: 1) teacher's activities, 2) students' activities and, 3) the achievement results. The adopted approach is a descriptive-quantitative one and the subject is the Class VII students of Islamic Junior High School in Indonesia. The data were obtained through direct observations in order to gain some knowledge of the teacher's and students' learning activities. The results of the students' learning activities were obtained through geometry tests. The research results showed that the teachers were able to implement the preplanned learning activities and their leaning activities may be able to improve the students' learning activities. Moreover, the five aspects of the scientific approach namely observing, asking questions, reasoning, attempting and presenting, were well implemented. The students' activities were also done as planned and all the aspects of the learning activities as stated in the approach may said to be well implemented. The mean value of students' learning results in groups was found to be 96; meanwhile their individual learning result was found to be 95 . This condition showed that the students' learning results were under a very good category.
\end{abstract}

Key Words: discovery learning, teacher's activities, students' activities, learning results, scientific

\section{INTRODUCTION}

Learning is one of factors that may determine the students' learning results (Lim \& Morris, 2009), so that learning innovations should always be made (In'am, 2012). Meanwhile Nur (2000) states that the learning system at school tending to be based on behaviorism becomes one of factors raising the conflict phenomenon at school environment.

Dealing with the learning of mathematics, many studies showed that mathematics materials are those with high failure risks and the students' achievement in this subject is at the mid-stage (Saad, 2004). The results were in line with the concern of the experts in 
mathematics with the students' problem in solving mathematical problems, but most teachers were aware of the condition. Mathematical problem solving is an abstract and complex process and this involves human thinking and human contemplative faculties (NCTM, 2000).

In order to solve the learning problems, some researchers have developed some learning models. Cholis (2006) and Yuwono (2006) developed a constructivism-based learning model for Junior High School Students, while Dwi (2006) gave a priority in the students' behavioural principles using cooperative based learning activities in Elementary schools.

Learning research concerning with discovery learning has shown that the learners have a high ability to follow very well, while the less ability group may increase the ability itself (Alex \& Olubusuyi, 2013). However, the discovery learning emphasizing the extensive search through problem solving, processing of enhancing the learners' memory has a limitation. Concerning with this matter, it may cause less learning (Rittle-Johnson, 2006), so that the learners need ability to monitor the processes that have been learned to pay attention to what already have (Case, 1998; Kirschner et al, 2006). To pay attention is a factor which is needed for innovation in learning to improve the student's ability (Alex \& Olubusuyi, 2013).

The results showed that there are some innovations in the learning implementations, including learning development models. Learning innovation is an effort to create a program focused on the improvement of learning qualities, so that any learning activity really serves to improve the students' learning quality (Podhorsky \& Moore, 2006). Learning innovations must be made to enable the students to learn properly and also to make the teacher teach properly (In'am, 2015).

Joyce, et al. (2009) said that a learning model is a design that may be employed to design the curriculum, to make learning materials, and also to lead any learning activities well either in or out of the classroom. Meanwhile Eggen \& Kauchack (2009) suggested that a learning model is a learning perspective designed to attain certain learning objectives.

Meanwhile, theoretically it can be stated that the implementation of learning activities is a series of scientific activities as stated in the 2013 curriculum that has been implemented in certain schools as a pilot project that mandates the importance of a scientific approach. Such a scientific approach is a medium to implement the development of students' attitudes, competences and knowledge (Kemendikbud, 2013). Any activities appropriate for scientific work may be said as inductive reasoning, seeing any general conclusion may be obtained by basing it to an obtained specific thing.

Dealing with the implementation of the 2013 curriculum, in mathematics learning, there are various facts that have not been in line with the expectations as stated in the curriculum. Some education and trainings on the implementation of the curriculum have been given to teachers, but due to the limited time, the majority of the teacher's comprehension about the implementation of the learning activities has not met the expectation stated in the 2013 curriculum.

Although the learning activities have followed the 2013 curriculum, but the levels of varieties in teachers' creativities are still low. This condition may cause students to be bored with the learning activities, for example discussion is always held in each session so that the learning activities have not been made in line with the design of the 2013 curriculum. 
The student-centred learning system may be attained if teachers may use various flexible teaching strategies (Baxter \& Gray, 2001; Chase \& Geldenhuys, 2001). Appropriate and good teaching materials in mathematics cannot guarantee the attainment of the objective of the education and one of the important factors is the learning process that gives an emphasis on the students optimally, and one of the learning models that may fulfil the criteria is the discovery learning model.

\section{REVIEW OF LITERATURE}

\section{The Learning Model of the Discovery Learning}

The discovery learning model is one that gives opportunities to the students to find any information without help from the teacher (Saab et al.,2005; Hosnan, 2014). This model is known as a guided discovery method, where students are guided to discover a solution of a problem (Klahr\& Nigam, 2004). Discovery learning is proven to improve the quality of learning compared to conventional methods, and learners can improve their knowledge during the learning process (Martins \& Oyebanji, 2000; Bajah \& Asim, 2002).

Other than that, the discovery learning could make learning more meaningful for the students to understand the material being studied with the capability and the relevant information that he/she has (Mayer, 2003).

Through this model, students discover something they learn by themselves. It does not mean that what is found in the learning activities is really new, but they, because of their own efforts, may discover a solution to a problem they face in learning (Krischner, et. al, 2006; Hosnan, 2014). This discovery method is a component of the education implementation as heuristic learning, namely a learning model consisting of methods designed to make processoriented students being active: leading by them, finding by them, and making their own reflections during their learning activities.

A discovery learning model is a mental process where students assimilate a concept consisting of observing, grouping, hypothezing, explaining, measuring, and concluding (Klahr\& Nigam, 2004). It is through this way that students may experience mental processes by themselves; the teacher merely guides and instructs them.

Bruner suggests that the students learn through active participations using concepts and principles in order to get knowledge. It is necessary for students to make some discovery with the belief that a true learning is through personal discovery. Hosnan (2014) describes the steps in discovery learning as: 1) giving a stimulus; 2) identifying problems; 3) collecting data; 4) processing data; 5) verifying, and 6) making conclusions.

\section{A Scientific Approach}

The 2013 curriculum-based learning is implemented using three aspects namely attitude, knowledge, and skill (Kemendikbud, 2013). The aspect of attitude is intended to make the students know why, the aspect of skill brings the students to know how and the aspect of knowledge is intended to lead the students to know what. It is through the three aspects that the students will have an improvement and a balance between the ability to be a good person and to be a person with some knowledge to live decently covering the aspects of attitude, skilled knowledge competences (Hosnan, 2014).

\section{Observing}

The method of observing gives a priority on the meaningfulness of the learning process. The benefits of this method among others are that this gives real objects, the students feel happy and challenged, and the implementation is easy. 


\section{Asking Questions}

An effective teacher is the one who may know his/her students' competences and may inspire the students to improve and develop the aspects of their attitude, competence and knowledge. When asking a question, a teacher is also leading or guiding the students to learn well. When s/he is answering a question, s/he is also encouraging his/her students to become a good learner.

\section{Reasoning}

Reasoning is a systematic and logic thinking process or an empirical fact that should be observed to obtain a conclusion in the form of knowledge. The term to reason is equivalent with to associate instead of the translation of reasoning, although this term also means to reason. To reason in the learning context in the 2013 curriculum using the scientific approach refers to associative learning theory.

\section{Attempting}

In any effort to obtain real learning results, the students should make some trials, especially for appropriate materials of substances. In mathematics subject, the aspect of attempting is made through the implementation of the knowledge possessed to solve any mathematical problems.

\section{Presenting}

After the four stages are implemented, the fifth stage of the implementation of the scientific approach is presenting the findings or results obtained during the process. This activity may be done through representatives of groups if the implementation of the learning process is made using the cooperative model, but this may also be done through the presentation of the results by some students.

\section{Learning through Discovery Learning using a Scientific Approach}

This combination is the learning implementation of the results of the collaboration model of discovery learning consisting of six steps namely: 1) giving a stimulus; 2) identifying problems; 3) collecting data; processing data; 5) verifying, and 6) making conclusions. The six aspects are integrated with five aspects of the scientific approach, namely: 1) observing; 2) asking questions; 3) exploring; 4) associating, and 5) presenting, and the interrelation between the discovery learning and the scientific approach is presented in Table 1.

\section{METHOD}

A research will succeed if a good plan is made. A good plan may be realized by paying attention to the approach and the type of research that will be committed.

\section{The Approach and Types of the Research}

A proper approach to a research should be applied, and the approach of this present research is descriptive-quantitative in nature.

\section{The Research Subject}

The data of this research were those on the results of the validation of the learning design, teacher's activities during the learning activities and students' activities of the Class VII as the research subject, and the results of the learning material of the students' square forms. 
Tabel 1

A discovery learning model using a scientific approach

\begin{tabular}{l} 
Discovery Leaning Model \\
\hline Giving Stimulus \\
In this activity, the teacher gives stimulus that may be in the forms of \\
reading passage, or pictures or situation in line with learning materials \\
that will be discussed, so that the students get learning experiences of \\
observing conceptual knowledge through activities of reading, observing \\
a situation or looking at pictures.
\end{tabular}

Identifving problens at pictures.

From the stage, the students are required to find any problems they face, so that in this activity, the students are given experiences of asking questions, finding information and of formulating problems

Collecting data

At this stage, the students are given some experiences of looking for and collecting data/information that may be used to find solution to problems they encountered. This activity will also train them to be careful, accurate, and sincere and to habituate them to look for or to formulate various problem solving alternatives, if one alternative fails.

Processing data

The activity of processing data will train the students to attempt and to explore their conceptual knowledge competence to be applied to the real life, so that this activity will train them to the competence of thinking logically and applicative.

Verifying

This stage leads the students to verify the truth correctness of processing data through various activities, among others asking questions to classmates, discussing, or looking for relevant sources either from books or another media, and associating them so that a conclusion may be made.

Making conclusions

In this activity, the students are led to generalize their conclusion into Scientific Approach Observing

Asking questions

Reasoning

similar event or problem, so that this activity may also train their metacognitive knowledge

The data of the validation results of the learning design were obtained from experts in learning, the teacher's activities from the teacher's activities and the students' activities from the students. Moreover, the data were obtained from the results of the interviews made with the teachers doing the learning activities and with the students at Class VII of the Junior High School Malang, East Java, Indonesia as the research subject. This research highlighted the geometry learning through the discovery learning. The students of Class VII were designated as the subjects to implement the learning design. Moreover, based on the obtained data, the students in the class belong to the average with good ability.

\section{The Technique of Data Collection}

The techniques employed in the data collection are giving instrument and using document and observing learning activities. Meanwhile the instrument of the learning implementation is used to evaluate the teacher's activities during the learning process, and the instrument of students' activities is intended to obtain the information during the 
learning implementation, and the instrument to get the students' competence in learning results was tests dealing with the square form material.

\section{Technique of Data Analysis}

The data analysis is done by describing the research results. On the basis of the observation instrument, it can be stated that the teacher's and students' activities are shown using frequency, percentage and mean. Moreover, based on the observation results during the learning implementation, the teacher's activities dealing with giving the stimulus, leading the problem identification, collecting the data combined with aspects of the scientific approach namely observing, asking questions, exploring, associating and presenting can be obtained. Meanwhile the students' learning results are given scores to get the learning competence conversed into grades.

\section{FINDINGS}

\section{The Teacher's Activities during the Learning Implementation}

The teacher's activities during the application of the Discovery Learning method with the scientific approach are divided into two. First is that whether the teacher's activities are done in accordance with the prepared learning design and second is the scientific approach adopted by the teachers based on Table 2, the learning activities lasted in line with the design made by the teacher and on the basis of the validation results obtained from two validators,. It is shown that the learning design is said to be valid because there is a suitability between the criteria in the learning design and the implementation of the learning activities using the Discovery Learning with a scientific approach on the materials of recognizing elements of a plain. Dealing with the results of observation on the learning design, all stated in the category, from apperception to enclosing activities, were always done by the teacher.

Concerning with the teacher's activities, it can be stated that anything written in the learning design had been done in each session. The activities were from apperception to evaluation. The aspects of the discovery learning method the teacher done are as follows:

\section{Giving Stimulus to the Students}

The teacher's activities in giving stimulus were for instances relating the material to be discussed with previous materials, giving questions, presenting the advantages of learning the materials that would be discussed, giving the examples of the uses of the materials and giving an orientation in observing pictures. The activities were intended to enable the students to understand the learning materials easily. These activities, on the basis of the observer's evaluation, could be done well during the learning process.

\section{Stimulating the Students to Identify Problems}

The learning activity made by the teacher at this stage during the explanation of the material and the problem solving was for instance when the students made discussions in groups to solve the problem by consulting the materials in the supplementary books and looking at the materials presented by the teacher through the Liquid Crystal Display (LCD). The teacher saw his students' making a discussion seriously and when a student did not understand something he asked a question. The teacher leads the student to look for the answer to the question by himself/herself. When s/he had difficulty in answering the problem, the teacher asked another student to help solve the problem. 


\section{Helping the Students Collect the Data}

The teacher facilitated and helped the students collect the data to do the students' worksheet and to understand the learning materials. In the process of their understanding the teacher used the questions in the worksheet or gave questions orally to make them try, observe and analyse by themselves. Individual tests were made twice at the end of each cycle, while the results of group works were obtained from the evaluation of the students' worksheets.

\section{Helping the Students Process the Data}

Data processing in this activity is intended to train students to try and to explore their conceptual competence. What the teacher made was to give some problem examples that might reason their conceptual knowledge. Therefore, there was a relationship between the activity of data collection and the data processing. When the students had a difficulty, the teacher found the best solution to the problem. The solution applied in the discovery learning was that the problem was presented to other groups that might have some opinion to solve the problem, but there was no idea, the teacher helped and explained it but also asked the students to discuss the problem together. The students were asked to think and to relate the concept and the problem to apply in the real life.

Table 2

Evaluation of the teacher's activities on the basis of the learning design

\begin{tabular}{|c|c|c|c|c|c|c|c|c|}
\hline \multirow{2}{*}{ Activities } & \multicolumn{6}{|c|}{ Meeting $n^{\text {th }}$} & \multirow{2}{*}{ Mean } & \multirow{2}{*}{ Note } \\
\hline & 1 & 2 & 3 & 4 & 5 & 6 & & \\
\hline Apperception & 4 & 4 & 4 & 4 & 4 & 4 & 4 & always \\
\hline $\begin{array}{l}\text { Presenting Competences and } \\
\text { Activities Planning }\end{array}$ & 4 & 4 & 4 & 4 & 4 & 4 & 4 & always \\
\hline Mastering Learning Materials & 4 & 4 & 3 & 4 & 4 & 4 & 3.8 & always \\
\hline $\begin{array}{l}\text { Applying the educating learning } \\
\text { strategies }\end{array}$ & 3 & 4 & 4 & 4 & 4 & 4 & 3.8 & always \\
\hline $\begin{array}{l}\text { Applying the Scientific Approach } \\
\text { Making use of learning }\end{array}$ & 4 & 4 & 4 & 4 & 4 & 4 & 4 & always \\
\hline $\begin{array}{l}\text { sources/mediaPemanfaat sumber } \\
\text { belajar/media during the learning } \\
\text { process }\end{array}$ & 4 & 4 & 3 & 4 & 3 & 3 & 3.5 & always \\
\hline $\begin{array}{l}\text { Involving the students in the learning } \\
\text { process }\end{array}$ & 4 & 4 & 3 & 4 & 4 & 4 & 4 & always \\
\hline Using a right and proper language & 4 & 4 & 3 & 4 & 3 & 4 & 3.7 & always \\
\hline Closing the learning activities & 4 & 3 & 4 & 4 & 3 & 4 & 3.7 & always \\
\hline
\end{tabular}

Note: $\bar{x} \leq 1=$ never, $1<\bar{x} \leq 2=$ sometimes, $2<\bar{x} \leq 3=$ often, $3<\bar{x} \leq 4=$ always Verifying

The teacher in this activity asked the students to recheck their work. This verification was made to recheck the problems that had been worked on before being presented before the class.

\section{Making Conclusions}

This activity began when the teacher asked the representative of a group to present the result of the discussion. After the students presented the results of the discussions and 
when there were different opinions among them, the teacher gave an opportunity to the group to express their opinions.

\section{Students' Activity in the Learning Implementation}

Learning activities made by the students in applying the discovery learning using the scientific approach are presented in Table 3. Based on the Table 3, it can be stated that as a whole, aspects of students' activities in the learning activities may be under the majority of always and the detailed activities are given below.

\section{Being Given Stimulus}

Activities in giving stimulus may encourage the students to observe, to ask questions and to reason. Stimulus was given by the teacher during the learning activities, and it is known that the stimulus was in the form of reading passage, or problems appropriate with the learning materials, so that the students may construct their conceptual knowledge.

\section{Identifying Problems}

The activity of identifying problems made by the students was to write what is known, what is asked, and how to solve it. An example of a student's work is presented in Figure1. Figure1 shows that the student was able to identify a problem, it is known from the fact that the students was able to write the four aspects found out using four similarities $\mathrm{A}=40^{\circ} ; \mathrm{B}=4 y ; \mathrm{C}=7 x$ and $\mathrm{D}=z$. The process of identifying a problem, for example, is seen from the fact that the student started working on the students' worksheet.

\begin{tabular}{|c|c|}
\hline 3. b. $40^{\circ}=A$ & a. $z^{\circ}=180^{\circ}-\left(65^{\circ}+50^{\circ}\right)$ \\
\hline $4 y=B$ & $=180^{\circ}-115^{\circ}$ \\
\hline $7 u=c$ & $=65^{\circ} / 2$ \\
\hline$z=D$ & $y^{\circ}=$ berseberangan dengan sudut $50^{\circ}$ \\
\hline$A=B=40^{\circ}=4 y=40$ & $u^{\circ}=180^{\circ}-\left(50^{\circ}+100^{\circ}\right)$ \\
\hline $4 y=40$ & $=180^{\circ}-150^{\circ}$ \\
\hline$y=10$ & $=30^{\circ} 2$ \\
\hline $360-(A+B)=240^{\circ}$ & \\
\hline $240^{\circ}=140^{\circ}$ & \\
\hline$C^{2}=140-720=C=D$ & \\
\hline$D=140=2$ & \\
\hline$C=140=76$ & \\
\hline$\frac{140}{7}=t$ & \\
\hline $20^{7} \ldots=10 \mathrm{~m}$ & \\
\hline
\end{tabular}

Figure 1

An Ability to Identify a Problem

Figure1 shows that the student is able to identify what is expected by the item, meaning that the student is able to identify the problem. 
The problem contains the process of what is known, what is asked for and how to solve it. Therefore, the activities in the scientific process are in the forms of observing, asking questions and reasoning.

\section{Collecting Data}

The process of collecting data was made by the students after observing the problem. The activity of observing the problem would produce the Figure of the problem and the question. The question was then answered by the group referring to the supplementary books and the materials in the LCD the teacher had given. The difficulty faced by the was asked to other groups or the teacher.

\section{Processing Data}

Questions in the students' worksheet contain three elements: what is known, what is asked for and the solution. What is known by the student would be related to the existing theories explained in the supplementary books used in solving the problems. The example of the solution is presented in Figure 2

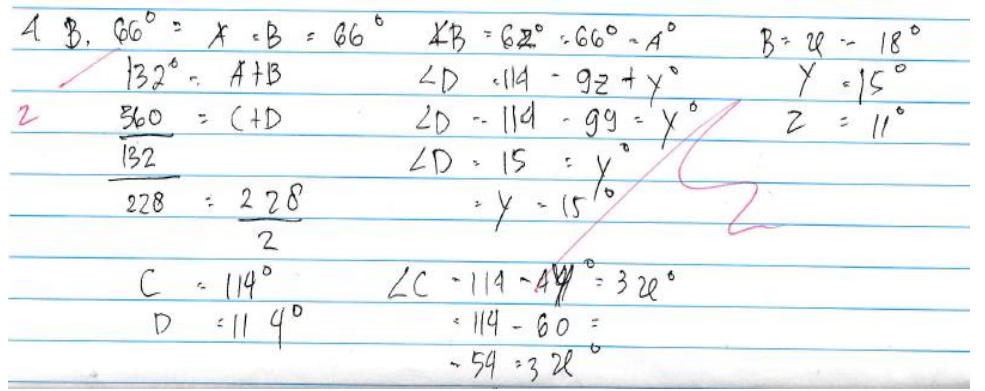

Figure 2

An Ability of Processing Data

Figure 2 indicates that the student is able to deal with the problem as depicted in figure 1. It shows that the student has the competency at the data processing stage.

The next step in applying the Discovery Learning is to process the data. The activity in processing the data, for example, is that of solving a problem. After the student understood the problem, then he was looking for any theory relevant to the problem. What is known in the problem and what is in the theory were then applied in the process of solving the problem.

\section{Verifying}

This activity was made by the student after they completed doing the problem. Verification means rechecking of what has been done using the existing theory. This rechecking was made by the students by rereading the problem, and then a discussion was made again from making sure of an answer to making a conclusion. Verification was also made before the activity of presentation by any groups that did not have a turn to make presentation in front of the class. The groups should watch and paid attention to what was being presented by another group. Moreover, the groups should also check the 
validity of what was being explained and what was being done by the group and also theories in the supplementary books.

Table 3

Students' Activities during the Learning Process

\begin{tabular}{|c|c|c|c|c|c|c|c|c|c|}
\hline \multirow{2}{*}{$\begin{array}{l}\text { Students' } \\
\text { Activities }\end{array}$} & \multirow{2}{*}{ Indicator } & \multicolumn{6}{|c|}{ Meeting $n^{\text {th }}$} & \multirow{2}{*}{ Mean } & \multirow{2}{*}{ Note } \\
\hline & & 1 & 2 & 3 & 4 & 5 & 6 & & \\
\hline \multirow{2}{*}{ Observing } & $\begin{array}{l}\text { Making careful observations of } \\
\text { the presented object }\end{array}$ & 3 & 4 & 3 & 4 & 4 & 3 & 3.5 & Always \\
\hline & $\begin{array}{l}\text { Taking a notes of the observation } \\
\text { made }\end{array}$ & 3 & 3 & 4 & 4 & 4 & 3 & 3.5 & Always \\
\hline \multirow{3}{*}{$\begin{array}{l}\text { Asking } \\
\text { Questions }\end{array}$} & $\begin{array}{l}\text { Asking questions about the results } \\
\text { of observation }\end{array}$ & 3 & 3 & 3 & 2 & 3 & 3 & 2.8 & Often \\
\hline & $\begin{array}{l}\text { Making questions and answers } \\
\text { with the teacher or classmates }\end{array}$ & 3 & 3 & 2 & 3 & 3 & 3 & 2.8 & Often \\
\hline & $\begin{array}{l}\text { Be willing to take and give of } \\
\text { ideas }\end{array}$ & 3 & 2 & 2 & 3 & 3 & 3 & 2.6 & Often \\
\hline \multirow{2}{*}{ Reasoning } & $\begin{array}{l}\text { Looking for data/information to } \\
\text { solve problems }\end{array}$ & 3 & 3 & 3 & 3 & 3 & 4 & 3 & Always \\
\hline & $\begin{array}{l}\text { Making conclusions of results of } \\
\text { problem solving }\end{array}$ & 3 & 3 & 3 & 4 & 4 & 4 & 3.5 & Always \\
\hline \multirow{2}{*}{ Attempting } & $\begin{array}{l}\text { Solving problems using the } \\
\text { concept learned }\end{array}$ & 3 & 4 & 4 & 4 & 4 & 4 & 3.8 & Always \\
\hline & $\begin{array}{l}\text { Doing the exercises, the teacher } \\
\text { gave }\end{array}$ & 3 & 4 & 4 & 4 & 4 & 4 & 3.8 & Always \\
\hline \multirow{3}{*}{$\begin{array}{l}\text { Net- } \\
\text { working }\end{array}$} & $\begin{array}{l}\text { Presenting the resultso f group } \\
\text { discussions }\end{array}$ & 3 & 4 & 4 & 4 & 4 & 4 & 3.8 & Always \\
\hline & $\begin{array}{l}\text { Writing the results of group } \\
\text { discussions }\end{array}$ & 3 & 4 & 4 & 4 & 4 & 4 & 3.8 & Always \\
\hline & $\begin{array}{l}\text { Presenting the results of group } \\
\text { discussion }\end{array}$ & 3 & 4 & 4 & 4 & 4 & 3 & 3.6 & Always \\
\hline
\end{tabular}

Note: $\bar{x} \leq 1=$ never, $1<\bar{x} \leq 2=$ sometimes, $2<\bar{x} \leq 3=$ often, $3<\bar{x} \leq 4=$ always Making Conclusions

Making conclusions may be viewed from two activities: group and individual activities. The scientific activity either in group or individual activities was intended to construct networks. The group activity was made when the students held a discussion before presentation in front of other groups. The objective of the discussion was to review what had been done and also to know whether what was discussed and done were right or not. A conclusion was made among the members of the group. An individual activity was made when a presenter finished doing her/his job but there were different opinions about something with all groups. In this case, the teacher helped students to find out a solution and make conclusion. Therefore, the emphasis of this activity was on individual understandings and conclusion was made individually although it was done together. 


\section{The Results of the Students' Learning in Mathematics during the Learning Implementation}

The students' learning results were taken in two matters namely group scores obtained from the students' worksheets. The average of the group scores in each cycle is as follows:

Table 4

The Results of Group Scores

\begin{tabular}{clccccccl}
\hline \multirow{2}{*}{ No } & \multirow{2}{*}{ Group } & \multicolumn{7}{c}{ Meeting $n^{\text {th }}$} \\
\cline { 2 - 7 } & & 1 & 2 & 3 & 4 & 5 & 6 & \multirow{2}{*}{ Mean } \\
\hline 1 & Group 1 & 96 & 100 & 100 & 100 & 92 & 100 & 98 \\
2 & Group 2 & 75 & 96 & 86 & 100 & 100 & 92 & 91.5 \\
3 & Group 3 & 100 & 100 & 100 & 100 & 100 & 100 & 100 \\
4 & Group 4 & 100 & 96 & 92 & 92 & 100 & 100 & 97 \\
5 & Group 5 & 92 & 100 & 83 & 100 & 100 & 92 & 94.5 \\
6 & Group 6 & 100 & 100 & 70 & 100 & 100 & 100 & 95 \\
\hline $\bar{x}$ & & & & & & & & 96
\end{tabular}

On the basis of Table 4, the mean group score was 96, and individual score was 95 when the discovery learning method was applied. Before the evaluation, some conditions were made: the seats were arranged in such a way that the students could not ask one another. In the application of the discovery learning method, besides individual and group evaluations, the evaluation of the process was also taken into account. The evaluation of the process in this learning activity became clear. And the teacher made the evaluation by identifying active or passive students during the learning activity.

\section{DISCUSSION}

The results presented above prove that studying geometry through discovery learning using a scientific approach can significantly promote student ability. It shows that teacher innovation in learning needs to be encouraged and it is worthy that the innovation should be appropriate with the situation, condition, and delivered material.

In the research made by Rahman and Samsul (2014) on the Effect of the Use of Discovery Learning Method on the Mathematical Analogy Competence of the Students of SMK Al-Ikhsan Pamarican, Ciamis regency it was found that the improvement of the students' mathematical analogy competence taught using the Discovery Learning method was higher than the one taught using Expository method.

Similarly, the study conducted by Alex and Olubusuyi (2013) showed that the discovery learning is very useful for students who have a high ability and also can enhance his/her ability for those in the medium category. Other than that, discovery learning is more effective than conventional learning and it improves the ability of students (Martin \& Oyebanji, 2000; Bajah \& Asim, 2002)

Moreover, there is a research made by Afendi (2012) on the Effectiveness of Discovery Learning Method on the Learning Results of Class X SMK Diponegoro Yogyakarta. The research showed that the students' achievement was better when Discovery Learning method was applied in teaching compared to conventional methods. 


\section{CONCLUSION}

The teacher's activity during the implementation of geometry learning using the Discovery Learning with a Scientific Approach is in line with a valid learning design. The teacher in this activity becomes more innovative and the teacher's ability improves. The improvement is seen when the teacher prepares his learning activity well in order to reach the intended learning objective.

The students' activities during the implementation of the geometry learning using the Discovery Learning with Scientific approach are said that the most often used activity made by the students in the scientific approach is giving stimulus namely observing and asking questions, while the most often used activity of identifying problems using scientific approach is reasoning. During the data collection, the most often used activity made by the students is observing and asking questions. This also happens during the data collection. But during the implementation of observing, asking questions and reasoning activities, the most often used activity made by the teacher in the scientific approach is observing and reasoning. Meanwhile, the results of student's learning in geometry during the implementation for this learning may said to be very good.

\section{REFERENCES}

Afendi, A (2012). Efektivitas metode pembelajaran penemuan terhadap hasil belajar kelas $X$ SMK Diponegoro (The Effectiveness of discovery learning method on the learning results of class X SMK Diponegoro), Skripsi, Yogyakarta

Alex, A.M \& Olubusuyi, M.F (2013). Guided-discovery Learning Strategy and Senior School Students Performance in Mathematics in Ejigbo, Nigeria. Journal of Education and Practice Vol.4, No.12, 2013

Bajah, S.T \& Asim, A.E (2002) Construction and Science Learning Experimental evidence in a Nigerian Setting. World Council for Curriculum and Instruction (WCCI) Nigeria. 3 (1), 105-114

Baxter, S., \& Gray, C. (2001). The application of student centered learning approaches to clinical education. International Journal of Language \& Communication Disorder/Royal College of Speech \& Language Therapists, 36 (Supplement), 396-400

Case, R. (1998). The development of conceptual structures. In D. Kuhn \& R. S. Siegler (Eds.), Handbook of child psychology: Cognition, perception, and language (Vol. 2). New York, NY: Wiley

Chase, C. C., \& Geldenhuys, K. M. (2001). Student-cantered teaching in a large heterogeneous class. Medical Education, 35 (11), 1071

Cholis, S. (2006). Pembangunan model pengajaran dan pembelajaran matematik beracuan konstruktivisme untuk Pelajar SMP. Disertasi S-3 Pendidikan Matematika Universitas Negeri Surabaya (Developing the constructivism-based mathematics teaching and learning model for junior high school. Unpublished Dissertation, Mathematics Education, State University of Surabaya)

Dwi P U (2007). Pengembangan model pembelajaran kooperatif matematika yang berorientasi pada kepribadian siswa di sekolah dasar Disertasi S-3 Pendidikan Matematika 
Universitas Negeri Surabaya (Developing the students' character-oriented mathematics cooperative learning model for elementary school). Unpublished Dissertation, Mathematics Education, State University of Surabaya)

Eggen \& Kauchak (2009). Methods of teaching: promoting students learning in K-12 classrooms, New Jersey USA: Pearson Education, Inc, Publishing as Allyn \& Bacon.

Hosnan, M. (2014). Pendekatan saintifik dan kontekstual dalam pembelajaran abad 21. (Scientific and contextual approach to 21 century learning) Jakarta: Ghalia Indah

In'am, A (2012). Model pembelajaran matematika berbasis metakognitif (Mathematics learning model base of metacognitive) Malang: Selaras

In'am, A. (2015). Kebijakan pemberdayaan guru: analisis dimensi dan implementasi, (The policy of teachers' empowerment: the analysis of dimension and implementation) Yogyakarta: Pohon Cahaya

Joyce, Bruce \& Weil. (2009). Models of teaching. New Jersey USA: Pearson Education, Inc, Publishing as Allyn\& Bacon

Kemendikbud (2013). Konsep pendekatan saintifik Makalah Diklat Guru tentang Implementasi Kurikulum 2013. (The concept of scientific approach) Working Paper presented at the Education and Training for Teachers on the Implementation of the 2013 Curriculum

Kirschner, P. A., Sweller, J., \& Clark, R. E. (2006). Why minimal guidance during instruction does not work: An analysis of the failure of constructivist, discovery, problembased, experiential, and inquiry-based teaching. Educational Psycho-logist, 41, 75-86

Klahr, D., \& Nigam, M. (2004). The equivalence of learning paths in early science instruction: Effects of direct instruction and discovery learning. Psychological Science, 15, 661-667.

Lim, D. H., \& Morris, M. L. (2009). Learner and Instructional Factors Influencing Learning Outcomes within a Blended Learning Environment. Educational Technology \& Society, 12 (4), 282-293

Martins, O. O. and Oyebanji, R. K. (2000). The effects of inquiry and lecture teaching approaches on the cognitive achievement of integrated science students. Journal of Science Teachers' Association of Nigeria. 35 (1\&2) 25-30

Mayer, R. E. (2003). Learning and instruction. Upper Saddle River, NJ: Prentice Hall

National Council of Teachers of Mathematics (2000). Principles and Standards for School Mathematics.Reston, VA: NCTM

Nur, M (2000). Pengajaran berpusat kepada siswa dan pendekatan konstruktivis dalam pengajaran. Pusat Pendidikan Sains dan Matematika Sekolah. Unesa-Surabaya (The students-centred teaching and the constructivism approach to teaching. The Centre for Science and School Mathematics. Unesa-Surabaya).

Podhorsky, C.\& Moore, V. (2006). Issues in curriculum: improving instructional practice through lesson study. http://www.lessonstudy.net Retrieved 2 Nopember 2010.

Rahman, R \& Samsul, R (2014). Pengaruh penggunaan metode pembelajaran penemuan pada kompetensi analogi matematis siswa SMK Al-Ihsan Pamarican, Ciamis (The effect of 
the use of discovery learning method on the mathematical analogy competence of the students of SMK Al-Ikhsan Pamarican, Ciamis) Infinity 3(1), 33-58

Rittle-Johnson, B. (2006). Promoting transfer: Effects of self-explanation and direct instruction. Child Development, 77, 1-15

Saab, N., et al. (2005). Communication in collaborative discovery learning, British Journal of Educational Psychology, 75, 603-621

Saad, N. et al. (2004). The Metacognitive treatment of the science stream of the fourth year students in solving supplementary mathematical problems. Mathematics Department, Faculty Science and Technology Sultan Idris Education University

Yuwono, I (2006). Pengembangan model pembelajaran matematika secara membumi, Disertasi S-3 Pendidikan Matematika, Universitas Negeri Surabaya (Developing the mathematics learning model earthly. dissertation, Mathematics Education, State University of Surabaya).

\section{Turkish Abstract}

\section{Bilimsel Bir Yaklaşım Kullanarak Buluş Yoluyla Geometri Öğrenmek}

Mevcut araştırmanın amacı, 3 farklı bakış açısından oluşan bilimsel bir yolla geometri öğrenme uygulamasını analiz etmektir: 1) öğretmen etkinlikleri, 2) öğrenci etkinlikleri ve başarı sonuçları. Uygulanan yaklaşım tanımlayıcı nicel bir yaklaşım olup denekler, Endonezya'da bir islami lisenin 7. sınıf öğrencileridir. Veriler öğretmenlerin ve öğrencilerin öğrenme etkinlikleriyle ilgili bilgi toplamak için doğrudan gözlem yoluyla elde edilmiştir. Öğrencilerin öğrenme etkinlikleri sonuçları geometri testiyle elde edilmiştir. Araştırma sonuçları, öğretmenlerin önceden planlanmış öğrenme etkinliklerini uygulayabileceklerini, bu öğrenme etkinliklerinin öğrencilerin öğrenme faaliyetlerini geliştirebileceğini göstermiştir. Buna ek olarak gözlem, sorgulama, akıl yürütme, etkinliklere katılma ve sunma gibi beș bilimsel bakıș açısı uygulanmıștır. Öğrencilerin faaliyetleri planlandığı gibi yapılmışırı ve yaklaşımda belirtilmiş bütün öğrenme etkinlikleri iyi bir şekilde uygulanmıştır. Öğrencilerin öğrenme sonuçları gruplar içinde ortalama 96 iken bireysel öğrenme sonuçları 95'tir. Bu durum öğrencilerin öğrenme sonuçlarının çok iyi olarak sinıflandırılabileceğini göstermiştir.

Anahtar Kelimeler: buluş yoluyla öğrenme, öğretmen etkinlikleri, öğrenci etkinlikleri, öğrenme sonuçları, bilimsel

\section{French Abstract}

Apprentissage de Géométrie par Apprentissage de Découverte Utilisant une Approche Scientifique

L'objectif de cette recherche présente est d'analyser la mise en oeuvre de géométrie apprenant par un apprentissage scientifique consistant de trois aspects: 1) les activités du professeur et 2) les activités des étudiants et, l'accomplissement résultent. L'approche adoptée est une descriptivequantitative et le sujet est les étudiants la Classe VII de Collège Islamique en Indonésie. Les données ont été obtenues par des observations directes pour gagner un peu de connaissance des activités d'apprentissage du professeur et étudiants. Les résultats des activités d'apprentissage des étudiants ont été obtenus par des tests de géométrie. Les résultats de recherche ont montré que les professeurs ont pu mettre en oeuvre le preplanned l'apprentissage d'activités et leurs activités 
penchant peut pouvoir améliorer les activités d'apprentissage des étudiants. De plus, les cinq aspects de l'approche scientifique observant à savoir, posant des questions, le raisonnement, la tentative et la présentation, ont été bien mis en œuvre. Les activités des étudiants ont été aussi faites aussi planifié et tous les aspects des activités apprenantes qu'exposé dans l'approche peuvent dire pour être bien mis en œuvre. L'apprentissage des étudiants aboutit aux groupes étaient 96 dans moyen, en attendant leur individu apprenant le résultat était 95 . Cette condition a montré que les résultats d'apprentissage des étudiants étaient sous une très bonne catégorie.

Mots Clés: apprentissage de découverte, les activités de professeur, les activités d'étudiants, apprentissage de résultats, scientifiques

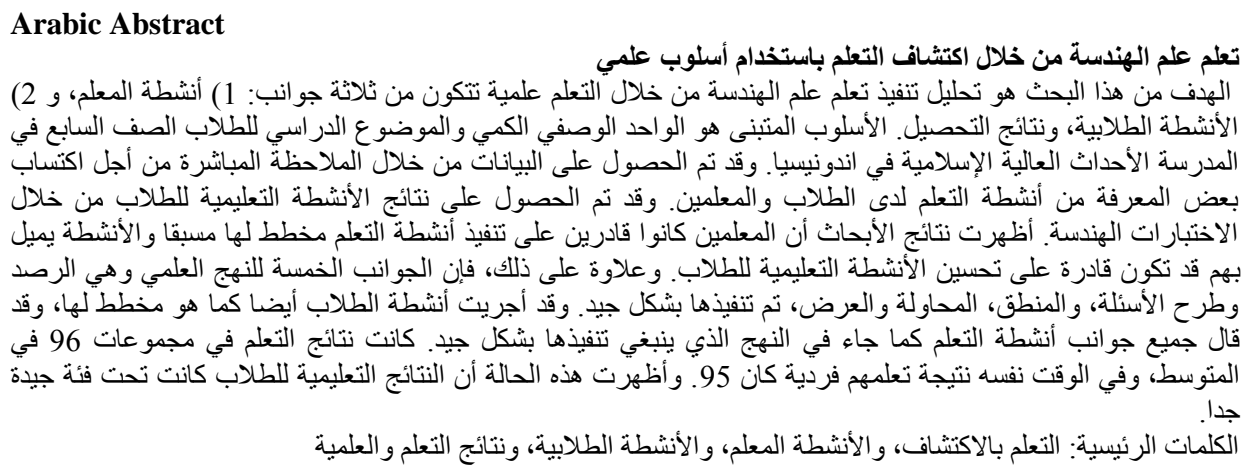

\section{German Abstract}

\section{Lernen Geometrie durch Entdeckung Lernen mit einem wissenschaftlichen Ansatz}

Das Ziel dieser vorliegenden Forschung ist es, die Umsetzung der Lerngeometrie durch ein wissenschaftliches Lernen, bestehend aus drei Aspekten zu analysieren: 1) Aktivitäten des Lehrers und 2) die Aktivitäten der Schüler und die Resultat der Ergebnisse. Der Ansatz ist eine deskriptiv-quantitative und das Thema ist die Schüler Klasse VII der Islamischen Oberschule in Indonesien. Die Daten wurden durch direkte Beobachtungen erhalten, um ein gewisses Wissen über die Lehrer und Schüler Lernaktivitäten zu gewinnen. Die Ergebnisse der Lernaktivitäten wurden durch Geometrieversuche ermittelt. Die Forschungsergebnisse zeigten, dass die Lehrkräfte in der Lage waren, die vorgeplanten Lernaktivitäten umzusetzen und ihre schiefen Aktivitäten können die Lernaktivitäten der Schüler verbessern. Darüber hinaus wurden die fünf Aspekte des wissenschaftlichen Ansatzes, nämlich Beobachten, Fragen, Argumentieren, Versuchen und Präsentieren, gut umgesetzt. Die Aktivitäten der Kursteilnehmer wurden auch wie geplant durchgeführt und alle Aspekte der Lerntätigkeiten, wie in der Annäherung angegeben, können gut umgesetzt werden. Die Lernergebnisse der Schüler in Gruppen waren 96 im Durchschnitt, mittlerweile war ihr individuelles Lernergebnis 95. Dieser Zustand zeigte, dass die Lernerfolge der Schüler unter einer sehr guten Kategorie waren.

Schlüsselwörter: entdeckungs-lernen, lehrer-aktivitäten, aktivitäten der schüler, lernergebnisse, wissenschaftliche 


\section{Malaysian Abstract \\ Mempelajari Geometry Melalui Pembelajaran Penemuan Menggunakan Pendekatan Saintifik}

Objektif kajian ini adalah untuk menganalisis pelaksanaan pembelajaran geometri melalui pembelajaran sains yang terdiri daripada tiga aspek: 1) Aktiviti guru, dan 2) aktiviti pelajar dan, keputusan pencapaian pelajar. Pendekatan yang diguna pakai adalah deskriptif kuantitatif dan subjek adalah pelajar Kelas VII Islam Junior High School di Indonesia. Data yang telah diperoleh melalui pemerhatian secara langsung untuk mendapatkan beberapa pengetahuan tentang aktiviti pembelajaran pelajar dan guru. Keputusan aktiviti pembelajaran pelajar telah diperoleh melalui ujian geometri. Keputusan kajian menunjukkan bahawa guru-guru dapat melaksanakan aktiviti pembelajaran preplanned dan aktiviti bersandar mereka mungkin boleh meningkatkan aktiviti pembelajaran pelajar. Selain itu, lima aspek pendekatan saintifik iaitu memerhati, bertanya soalan, penaakulan, cuba dan menyampaikan, telah dilaksanakan dengan baik. Aktiviti pelajar juga telah dijalankan seperti yang dirancang dan semua aspek aktiviti pembelajaran seperti yang dinyatakan dalam pendekatan itu boleh dikatakan baik dilaksanakan. Hasil pembelajaran pelajar dalam kumpulan adalah 96 min, sementara itu hasil pembelajaran individu pula adalah 95. Keadaan ini menunjukkan bahawa pelajar hasil pembelajaran berada di bawah kategori yang sangat baik.

Kata Kunci: pembelajaran penemuan, aktiviti guru, aktiviti pelajar, hasil pembelajaran, saintifik

\section{Russian Abstract \\ Изучение Геометрии Через Дискавери с Использованием Научного Подхода}

Цель настоящего исследования анализ изучения геометрии через научное обоснование, состоящее из трех аспектов: 1) деятельность учителей, 2) деятельность студентов и, 3) достижение результатов. Подход описательно-количественный; субъектом явлются 7-го класса исламском неполной средней школы в Индонезии. Данные были получены путем прямого наблюдения для того, чтобы получить некоторые знания учительский и учебной деятельности учащихся. Результаты учебной деятельности учащихсия были получены через испытания по геометрии. Результаты исследования показали, что учителя были в состоянии претворять мероприятия заранее спланированного обучения и их деятельность может быть в состоянии улучшить учебную активносты учащихсия. Более того, пять аспектов научного подхода а именно наблюдение, заданные вопросы, рассуждения, попытки и представления, были хорошо реализованы. Деятельность учащихсия также была проведена как и планировалось, по всем аспектами учебной деятельносты. Результаты обучения в группах по 96\%, в то время как результаты индивидуального результаты обучения 95\%. Это показывает, что результаты обучения учащихсия относется к очень хорошей категории.

Ключевые Слова: обучение через Дискавери, преподавательская деятельность, учащихся мероприятия, результаты обучения, научный 